\title{
SELECTED FACTORS IN THE LOCATION OF SERVICE ACTIVITIES CONDUCTED BY SMALL ENTERPRISES
}

\author{
WYBRANE CZYNNIKI W PROCESIE LOKALIZACJI \\ DZIAŁALNOŚCI USŁUGOWEJ MAŁYCH PRZEDSIĘBIORSTW
}

https://doi.org/10.34739/zn.2020.52.03

\author{
Katarzyna Chrobocińska \\ Poland, University of Warmia and Mazury in Olsztyn, Faculty of Economics \\ ORCID: 0000-0003-3189-9912, katarzyna.chrobocinska@uwm.pl
}

JEL Classification Codes: D29, D81, D91

\begin{abstract}
The optimal location of a company is an asset in the market game; it is particularly important in activities where direct contact with the customer is essential. A well-used location of an entity increases the chance of achieving future profits; it is an important source of competitive advantage in service activities such as tourism, gastronomy or cosmetics. This study aimed to assess the most important factors that affect the location of small service enterprises operating in the Warmińsko-Mazurskie Voivodship. The survey was conducted in accordance with the standardised interview method, with a survey questionnaire and an in-depth interview. The research findings have shown that the ranking of location factors changes due to their importance for the development of business activity. The optimal location of small service companies offering services in a traditional and/or mixed manner was determined by the following factors: Internet access, the potential for the company's spatial expansion, the costs of maintaining the premises, the number of future customers and customer demographic characteristics, the closeness of competitors, the cost of building purchase/rental, local taxes and fees, and the availability of parking space.
\end{abstract}

Keywords: location factors, services, small enterprises, service activities

\begin{abstract}
Abstrakt: Optymalna lokalizacja przedsiębiorstwa jest atutem w grze rynkowej, ma to szczególne znaczenie w przypadku działalności, w których istotą jest bezpośredni kontakt z klientem. Stanowi ważne źródło przewagi konkurencyjnej w działalnościach usługowych m.in. turystycznej, gastronomicznej czy kosmetycznej. Dobrze wykorzystane umiejscowienie podmiotu przyczynia się do zwiększenia się szansy na osiągnięcie przyszłych zysków. Celem przeprowadzonego badania była ocena najważniejszych czynników warunkujących lokalizację małych firm usługowych funkcjonujących na terenie województwa warmińsko-mazurskiego. W przeprowadzonym badaniu wykorzystano metodę wywiadu standaryzowanego z kwestionariuszem ankiety oraz wywiadu pogłębionego. W świetle przeprowadzonych badań można stwierdzić, że zmienia się ranking czynników lokalizacyjnych z uwagi na ich znaczenie dla rozwoju działalności gospodarczej. W badanej populacji optymalną lokalizację małych przedsiębiorstw usługowych oferujących usługi w sposób tradycyjny lub/i mieszany określały następujące determinanty: dostęp do Internetu, możliwość rozwoju przestrzennego firmy, koszty utrzymania lokalu, liczba przyszłych oraz cechy demograficzne charakteryzujące klientów, bliskość konkurencji, koszty wynajmu/zakupu budynków, wysokość podatków i opłat lokalnych oraz dostępność miejsc parkingowych.
\end{abstract}

Słowa kluczowe: czynniki lokalizacyjne, usługi, małe przedsiębiorstwa, działalność usługowa

\section{Introduction}

Entrepreneurs starting up a business, and those already operating in the industry, are faced with the choice of finding a location that will provide the highest economic efficiency possible under the circumstances. With the changing environment, this process can be repeated several times, following which they can then redefine their location requirements and compare them with the advantages of a potential business location. The choice of the optimal place of operation is affected by a number of location factors, which can be understood as the "specific features of particular places with a direct impact on the investment outlays during the facility construction and the net profitability of business activity carried out in those places" (Godlewska 2005, p. 63). When verifying the business location, entities analyse and select a location that offers the optimal combination of factors creating the most suitable conditions for the entity to operate in a given industry. The right choice 
implies low capital expenditure incurred at the startup of the business and relatively low maintenance costs, which contribute to increased economic benefits and the development of the company.

The optimal location of a company is an asset in terms of the market advantage it bestows. This is particularly important in activities where direct contact with the customer is essential. It is an important source of competitive advantage in service activities such as tourism, gastronomy or cosmetics. The optimal location of an entity can only increase the chances of achieving future profits, which is the main objective of business activities. The optimal location facilitates access to adequate resources and large markets, and not only impacts on financial benefits (i.e. reduction of transport and production costs); but it also provides access to public funds or fiscal solutions made available locally. Such a location contributes to the saving of time and the amelioration of customer satisfaction, which affects the success of the business (Szymańska, Płaziak 2014, p. 72).

The local business environment is formed by location determinants, which, depending on the circumstances and due to the specificity of the activity and the particularity of place, may either stimulate or hinder growth. Creating preferential conditions should contribute to the economic development of a given region and increase its investment attractiveness (Kalinowski 2008, p. 27). The interest of future investors may be stimulated, e.g. by the improvement of technical infrastructure, low labour costs or tax relief. Such attractive elements are included in the offer of the Warmia and Mazury Special Economic Zone (WarmińskoMazurska Specjalna Strefa Ekonomiczna - W-M SSE), which has recorded an increase in the number of business initiatives as compared to previous years (Mielnicki 2020). The W-M SSE covers part of the Mazowieckie Voivodeship and the whole of the Warmińsko-Mazurskie Voivodeship. The latter has particular predispositions to carry out activities based on environmental values. Its advantages include mainly favourable natural conditions which enable the development of tourist services, agritourism and those branches of industry which can use renewable energy. The economic importance of service activities in the Warmińsko-Mazurskie voivodship is also reflected in the employment structure. In 2016, over half of the population had a job in the service sector (55.6\%) (CSO, BDL 2017). The report by Borowicz et al. (2016, p. 72) states that Warmińsko-Mazurskie Voivodship had the lowest investment attractiveness. However, the investment attractiveness is much higher in the service sector in subregions, e.g. in the Olsztyn subregion (which was classified as an area of high attractiveness). Future investors may be encouraged by the availability and quality of the labour force, accessible transport facilities, the well-developed business environment sector, and the high quality of the natural environment.

\section{Service location - theoretical aspects}

Service provision is a type of business activity which generates added value and gives benefits to customers (individuals or organisations) (Gilmore 2006, p. 11). Currently, services can be provided in a traditional and/or virtual way (e-services). The specificity of traditionally and virtually provided services manifests itself by the fact that: they are intangible (this applies to most services and e-services), the service cannot usually be separated from the person of the contractor (which is possible in e-services), the services cannot be possessed, services are complementary and substitutable and traditional services are less easily standardised compared to e-services. Moreover, the consumption of traditional services is simultaneous with their provision, whereas for e-services there is no such dependence (Mikołajczyk 2016, p.140). Currently, service providers may provide their services through many channels:

- in a traditional manner (each element of the service provision process takes place in real life - presentation, order and payment for the service),

- only virtually (all the elements of a service provision process take place on the Internet),

- in a mixed manner, i.e. virtually and traditionally (which means that the service may be presented on the Internet and its use - in real life) (Wolny, 2013, p. 17-18).

Thus, the activities of a service provider which provides services in a traditional manner, are stationary, which means that the service provision place is located in a geographically specified area. In such cases, the choice of the general and detailed location is important and is governed by the criteria of economic efficiency and compliance with the frequency of demand for particular types of services (Pluta-Olearnik 1993, p.74).

The choice of the optimal location for a service activity is a strategic decision, the consequences of which will be felt by the individual over the subsequent years. Therefore, a general and a specific location is determined. The general location of service activities usually consists in identifying the region, and then the place and districts whose location advantages will act for the benefit of specific service activities. Therefore, it should be preceded by the recognition and analysis of factors related to the company (e.g. material and personnel resources, market position, competition strategy) and its environment (e.g. economic, organisational, 
financial, urban) (Kucharska (ed.) 2010, p. 51). A selected location denotes selecting the best out of the pool of available solutions, involving the identification of a specific place in a material space, with an accepted combination of location factors.

The optimal location of business activity has been widely discussed in the literature. The precursor of considerations devoted to industrial plant location and who introduced the location factor into scientific considerations was A. Weber, who described it as "one of the clearly visible benefits that manifests itself in business activity when this activity is carried out at a specific point or area". By benefit, Weber meant savings in production costs'. Weber's considerations were about the optimal location of the industry, which could be determined by means of minimum transport costs for raw materials and finished products, which meant a reduction in production costs at a specific location (Budner 2004, p. 63, Chądzyński et al. 2007, p. 47, Wierzbicka 2015, p. 240). Researchers writing on location based their theories on the assumption that factors such as transport, costs of raw materials or labour will determine the choice of the optimal place of business activity in a geographical space. Other scholars have focused their attention on other aspects. However, location theories contain many ideas concerning the location of service activities. This issue is presented synthetically in Table 1.

Table 1. Circumstances favouring the location of service activities in selected location theories

\begin{tabular}{ll}
$\begin{array}{l}\text { Location theory } \\
\text { author }\end{array}$ & \multicolumn{1}{c}{ Determinants of the service activity location choice } \\
\hline & $\begin{array}{l}\text { The concept put forward by Thünen explains that the specialisation of agricultural production is } \\
\text { determined by its distance from the markets, which results in conducting various types of agricultural } \\
\text { production concentrically around the market - a big city. The heaviest and least durable agricultural } \\
\text { products will be produced closest to the market, which, for example, may explain the location of the } \\
\text { crop-purchase service facilities close to the place of production in the case of fragile fruit, which are }\end{array}$ \\
J.H. Thünen &
\end{tabular}
also perishable in transport.

Weber's model makes the choice of the optimal location of industrial enterprises dependent on the basic location factors, i.e. transport and labour costs, benefits of the agglomeration, with the optimal location being determined by the point of minimum transport costs. The agglomeration benefits are

A. Weber reflected in an over-proportional increase in efficiency with social and economic growth, but only up to a point. The presence of these benefits results from the concentration of functions and population in a small area, which in turn makes some cities develop faster and others more slowly. As a consequence, the location pattern of production and services is changing.

According to Lösch's concept, the optimal location of an entity should be a point where sales of production output is maximised, i.e. a place close to a ready market. The location of various

A. Lösch economic activities may be affected by the economic benefits of the production scale and low costs of transport services, which will contribute to the concentration of entities in a specific region. Otherwise, production is dispersed.

The central place theory assumes that the location of an entity depends on the hierarchy of the service centre, the central place is the source of services and goods provided to the surrounding W. Christaller area, but it also determines the deployment of lower-level centres. Location arrangement is the consequence of two opposing forces - striving to minimize expenses and maximise turnover and profits. This concept defines free and forced services, which are provided by entities within the city. The economic base theory deals with the role and functions of exo- and endogenous factors in the city's development, the latter being performed in order to satisfy the needs of their own population W. Sombart, and are oriented towards the development of social and welfare services. Exogenous functions K. Dziewoński contribute to region's development, while endogenous functions are a manifestation of the city's self-sufficiency, e.g. retail trade aims at serving the residents, and wholesale may perform an exogenous function.

F. Perooux, The theory of growth poles, i.e. polarised development, is a concept that maintains the uneven G. Myrdal, development that may result from the emergence of dynamic fields of activity that constitute the

A. Hirschman spirit of local growth and business development. It is represented here by the so-called "driving industry", which stimulates industry development which, in turn, initiates the emergence of the service sector, e.g. financial services.

In the Burgess concentric model, service and retail activities are located in the city centre with the

E.W. Burgess management zone, while the rest are located in circles surrounding the centre. Hoyt's concept H. Hoyt explained the development of the city in terms of sectors, with traffic routes being the main urbancreating factor. Industry is located in places with convenient rail or road transport, whereas service activities, e.g. wholesale trade, developed in one of the sectors.

Source: Gawlikowska-Hueckel (2003, p.23-24); Wieloński (2004, p. 15-16); Budner (2004, p. 26-61, 108); Nazarczuk (2013, p. 51); Brdulak et al. (2014, p. 2256); Wierzbicka (2015, p. 241). 
The optimal location of service activities is an important issue in some types of services, as the choice of location is reflected in the economic effects achieved (Budner 2007, p. 45). Therefore, the selection process should take into account the specific characteristics of the service activity in determining the requirements to be met by the location. The analysis of a specific location involves the clarification of the advantages and disadvantages of that location in the context of the activity in question. Depending on the balance of factors limiting and stimulating the development of activity in a given area, the location is more or less suited to the type of services provided by the entity (Wieloński 2004, p. 9). An entrepreneur should choose a place of business that will ensure the most effective use of resources with a specific outlay level or will allow achieving the assumed goal with a minimum amount of expenditure (Plawgo, Chilicka 2008, p. 63). Mikołajczyk (2016, p.139) rightly points out that "...today's decisions concerning the place of service activity focus on the choice between physical and/or virtual location, i.e. where to provide and/or sell services: in stationary facilities and/or on the Internet". Depending on the type of activity, the location value also changes, owing to which the right fit affects the choice of a convenient location. Therefore, for the business activity providing services at its facility, such factors as: easy customer access to the place of service provision, availability of parking spaces, good public transport, technical condition of the building and the presence of competitors play an important role. On the other hand, a company providing mass customer service via telephone or the Internet will not be dependent on these factors (Czubała et al. 2012 , p. 28). The most popular classifications of location factors are listed in Table 2.

It is not only the different types of location factors that have been considered in scientific studies, e.g. M.E. Porter (2001, p. 207) took an interest in the quality of the location in his competitiveness studies. The author specified the characteristics that determine the quality of location, formulating them as a so-called "diamond" (which consists of: company strategy and structure and competition, manufacturing factors, the nature of demand, and related and supporting industries). This researcher claimed that they can stimulate or hinder the functioning of a company, thus influencing the creation of competitive advantage at a specific location. The quality of location at a specific place may change, i.e. improve or deteriorate. Especially if the latter is the case, the entrepreneur will have to consider and decide whether it is not more rational to reconvert, relocate or de-locate in the circumstances compared to the current situation (Moszczyński, pp. 38-39).

Table 2. Classifications of location factors

\section{Types of location factors:}

- transport costs,

- labour costs,

- agglomeration-related benefits (e.g. production scale benefits; location-related benefits that result from the presence on a relatively small area of many enterprises of the same industry, which use qualified labour force, industry innovations and specialisation of service units which offer services to the industry; urbanisation-related benefits which arise from the use in the activities of the existing technical and social infrastructure, as well as the labour market, already created by the local economy, as well from the availability of information and innovation).

- closeness of markets (e.g. closeness of co-operators and suppliers),

- technical infrastructure (e.g. accessibility of a landline telephone network),

- space for business activities (e.g. cost of lease or purchase of existing facilities),

- production costs (e.g. labour costs),

- personnel (e.g. availability of core personnel),

- institutional support (np. friendliness of local offices),

- business support (e.g. assistance from business support institutions),

- education and schools (e.g. closeness of vocational schools),

- social infrastructure (e.g. state of safety in the town/commune).

- environmental (e.g.. mineral raw materials, water),

- spatial (e.g. shape and availability of terrain),

- economic (e.g. price level, inflation rate),

- socio-cultural (e.g. level of entrepreneurship),

- legal and administrative (e.g. fiscal policy, procedures of setting up an enterprise),

- technical and technological (e.g. progress in science and technology).

- natural (e.g. raw material base, availability of water, climate),

- non-natural (e.g. power supply base, labour force resources, market, technical infrastructure, science base, agglomerations). 
- hard (measurable - e.g. taxes, subsidies, market, qualified labour force supply),

- soft (immeasurable - e.g. social climate, attractiveness of the town, cultural offer, knowledge, institutions in the region - related to the quality and efficiency of public administration).

- business-related (e.g. closeness of markets, availability of raw materials, closeness of consumers, closeness

of other enterprises of the same industry)

- national, regional and local factors (e.g. fiscal burdens - CIT, country image, financial relief and incentives -

investment relief),

- labour market (e.g. labour force resources and availability, labour quality, organisational culture),

- cost-related (e.g. investment cost, labour cost, operational costs)

- quality of life (e.g. cultural factors, availability of education, terrain attractiveness).

- natural,

- economic and technical,

- institutional.

- production-related

- distribution-related

- organisational.

- external,

- internal.

Source: Kalinowski et al. (1997, p. 21-40) Wieloński (2004, p. 38), Waldziński (2005, p. 39), Budner (2007, p. 43-58,111), Plawgo,

Chylicka (2008, p. 68-69), Celińska-Janowicz (2009, p.108), Wierzbicka (2015, p. 246-247).

The dimension of location factors in service activities has also changed, which is illustrated in the results of the 1960s studies by Bergin and Eagan and the 1990s study by Brenke (Table 3). With the development of civilization and technology, which often manifests itself in changes in the city's infrastructure, numerous new threats appear, hindering and even limiting the progress and further development of the enterprise (Matejun, Szymańska 2013, p. 150).

Table 3. Ranking of location factors in terms of their importance to the business activity development in the 1960s and 1990s.

\begin{tabular}{|c|c|c|c|}
\hline No. & Findings of the Bergin and Eagan study (1964) & No. & Findings of the Brenke study (1996) \\
\hline 1 & Easiness of labour force recruitment & 1 & Closeness of markets \\
\hline 2 & Convenient links to the market & 2 & Supportive measures for business activity \\
\hline 3 & Possibility of purchasing buildings or other real property & 3 & Cost of labour \\
\hline 4 & Cost of labour & 4 & Labour force qualification \\
\hline 5 & Availability of raw materials & 5 & Closeness to motorways \\
\hline 6 & Weaker influence of trade unions & 6 & Closeness of suppliers \\
\hline 7 & Local cooperation opportunities & 7 & Costs of energy \\
\hline 8 & Enterprise headquarters & 8 & Services provided by local banks \\
\hline 9 & Climate & 9 & Support from chambers of commerce \\
\hline 10 & Transport costs & 10 & Positive image of the town and the region \\
\hline 11 & Sufficient amount of power & 11 & Support for entrepreneurship \\
\hline 12 & Centre for special industry & 12 & Land prices \\
\hline 13 & Transport facilities & 13 & Local fees \\
\hline 14 & Decentralisation of activities & 14 & Cost of leasing industrial facilities \\
\hline 15 & Beneficial structure of taxes & 15 & Municipal administration \\
\hline \multirow[t]{9}{*}{16} & Financial aid & 16 & Closeness of universities \\
\hline & & 17 & Closeness of research institutes \\
\hline & & 18 & Municipal public transport \\
\hline & & 19 & Flats \\
\hline & & 20 & Healthcare facilities \\
\hline & & 21 & Air connections \\
\hline & & 22 & Supraregional railway connections \\
\hline & & 23 & Cultural offer \\
\hline & & 24 & Leisure opportunities \\
\hline
\end{tabular}




\section{Study methodology}

The study aimed to assess the major factors which affect the location of service activities. 140 serviceproviding enterprises in the Warmińsko-Mazurskie Voivodship declared their willingness to participate in the study in 2017. Data verification of the selection criteria for the study population resulted in the qualification of 95 respondents. The sample selection was qualified by certain factors and the following verification criteria were applied for the study population:

- nature of the activities (production or service activities), which excluded non-service enterprises,

- annual average employment level during the past two years, which gave a group of small enterprises employing 1 to 49 people,

- service provision and sale in a traditional or mixed manner, which gave a group for which the location in a geographic area might be important before or during the service provision process.

The majority of the respondents were women aged 25-40 years, with secondary education, running small enterprises for 2-5 years. Moreover, enterprises in the study population provided services mainly to the local market. The study population was diverse with respect to the type of services, the largest group (25\%) provided accommodation-related or gastronomic services. Fewer respondents $(20 \%)$ provided cosmetic services, retail or wholesale trade outlets $(20 \%)$, carpentry services $(19 \%)$, accounting $(8 \%)$ or transport services (8\%) (Fig. 1).

The study applied the method of a standardised interview with a survey questionnaire including grouped location factors. The survey questionnaire contained closed, scaled questions (4-point scale with no neutral point - a forced-choice scale). An indepth interview was also conducted to clarify doubts. The respondents' task was to assess the impact of the presented location factors on the choice of a specific place in the economic space as a target service provision location. The selection of location factors was based on the literature on the subject; and the questionnaire included those most frequently mentioned in the literature (Kalinowski et al. 1997, p. 21-40, Wieloński 2004, p. 38, Budner 2007, pp. 43-58,111, Wierzbicka 2015, p. 246-247, Szymańska, Płaziak 2014, p. 77). The findings of the research were presented with the percentage of indications with the highest scores for particular location factors, which allowed the most important location factors in the studied population to be ranked.

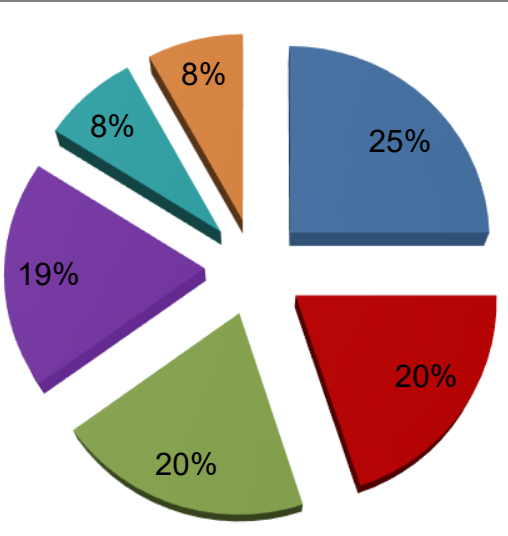

- provided accommodation-related or gastronomic services

- cosmetic services

- retail or wholesale trade outlets

- carpentry services

a accounting

- transport services

Figure 1. Structure of service activities in the studied population

Source: prepared by the author based on the study.

\section{Assessment of the location factors by the respondents}

The research was conducted with the participation of service entities that declared service provision in a traditional and mixed manner. Most of the respondents represented the hotel, cosmetic, commercial and furniture industries. This industry specificity was reflected in the frequency of demand for services. Services were purchased periodically in the study population; they were selectable, sometimes complex services with relatively high unit prices. Service purchasers were oriented towards direct contact with the service provider, the material conditions of service provision as well as the quality of attendance/service itself were important to them. In the provision of services, especially hotel, cosmetic and furniture services, the concept of mass customisation was often used (Doligalski 2013, p. 85-86, Wiechoczek 2018, p. 118 after: Pine 1993). In the provision of services in a traditional and mixed way, interactions were typically developed with each client during the service provision. The individual nature of the service provider-customer relation showed the strong involvement of both parties, so it can be assumed that it was a case of collaborative customisation. Direct contact with the customer was shown to be a platform for obtaining and verifying specific information that was used to create 
personalised value, which is expressed in the satisfaction of the buyer.

Many different factors influence customer satisfaction in service activities. Increased efforts to create a pleasant atmosphere, understanding and trust, which help to build customer loyalty, were observed in small service companies under study. Apart from competence or empathy factors, purchaser satisfaction is also influenced by material factors. This was confirmed, among others, by this study, in which the largest percentage of respondents $(92-81 \%$ of indications) who analysed the future location of their service activities included the following factors as the location determinants: Internet access, the possibility of spatial development of the company and the costs of maintaining the premises. Apart from these factors, the respondents included the number of future customers and customer demographic characteristics (specificity) among the most important factors determining the optimal location for economic efficiency. The entrepreneurs participating in the study reported that they used the Internet to present their activities (e.g. company website, facebook.com) to communicate with customers (e.g. moment.pl, booksy.com, booking.com, trivago.pl, delicious.pl, e-mail), to carry out online banking transactions, to collect information about innovations in the industry, or about competition strategies or for private purposes. Moreover, as positive customers themselves, they have often used $\mathrm{m}$-commerce in supply (Kune-Yao, Sheng-Yuan 2019, p. 4, Jang, Lee 2018, p. 16). However, the process of service provision itself was carried out in a traditional way.

The majority of respondents $(77-61 \%$ of indications) stated that the important factors they took into account when considering the location of their activity were: closeness of competitors, costs of renting/purchasing buildings, taxes and local fees and the availability of parking spaces. Slightly fewer respondents (68-50\% of indications) took into account the following when looking for the optimal location: the availability of the labour force, closeness of markets, quality of regional and local roads, spatial development of the surroundings, costs of lease/purchase of land, distance from residential buildings, costs of lease/purchase of flats, employee training opportunities, distance from the town centre, costs related to the adaptation of buildings to the activity, the quality of trunk roads, and the availability of information (Fig. 2).

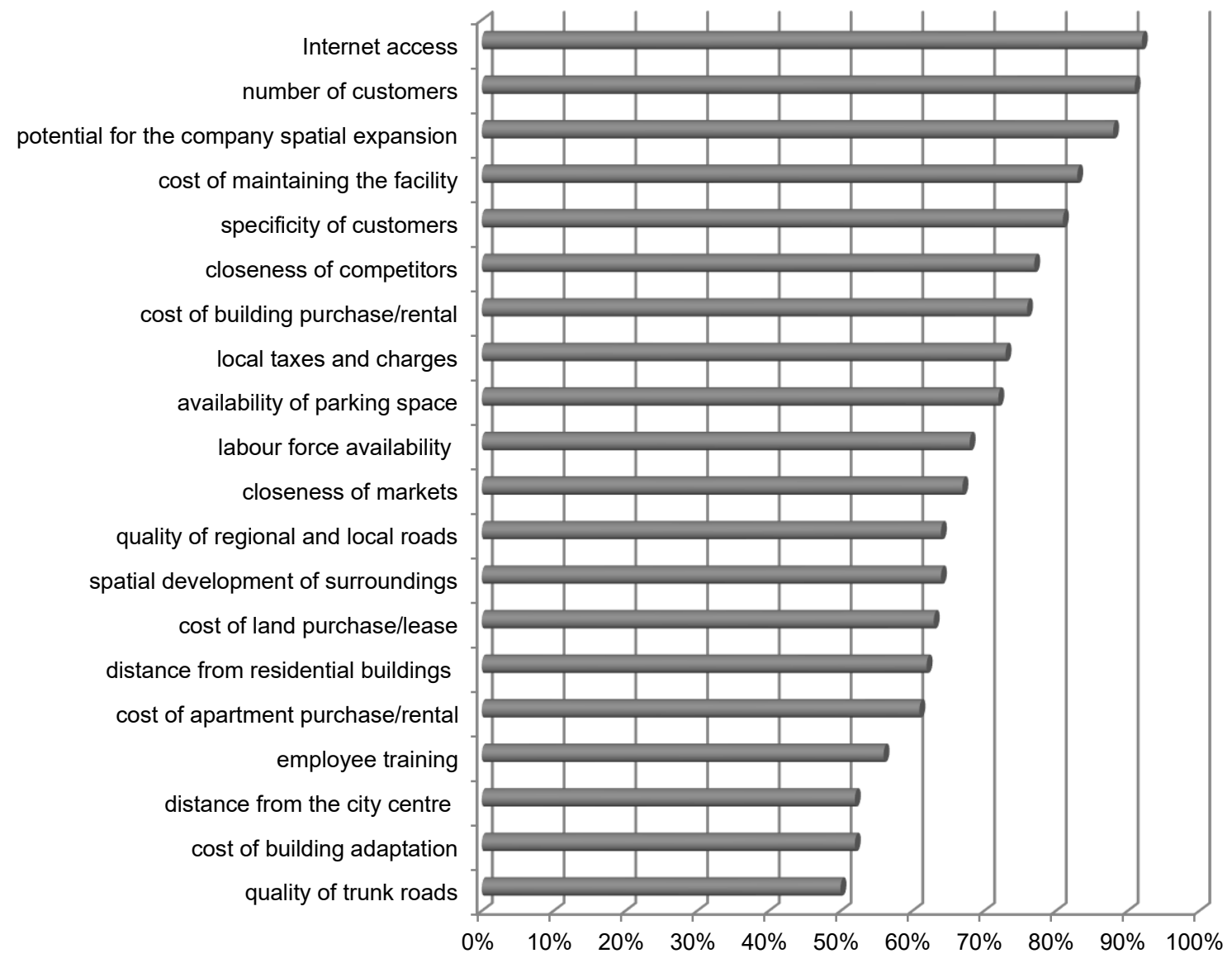

Figure 2. Determinants of service enterprise location in the study population

Source: prepared by the author as based on the study. 
The results of the research indicate that the respondents took the following factors into account much less frequently $(45-25 \%$ of indications) when deciding on the optimal location: accessibility of public transport, city development strategy, accessibility of regional programmes, closeness of suppliers and partners, time needed for obtaining administrative decisions, accessibility of financial institutions, closeness of universities, cultural offer, leisure opportunities, availability of office buildings, positive attitude of local authorities, cooperation with R\&D units, comprehensibility and coherence of administrative procedures, availability of means of production, quality of R\&D services, prices of R\&D services, closeness of consulting companies, attractive image of the region, specialists' salaries and the closeness of specialist schools. The opinions of the study participants indicate that other location factors in the analysis of the location of a service facility were of marginal importance (indications below 25\%) and they included: the costs of setting up a business, retraining or replacing employees, closeness of shops, hotels, healthcare facilities, vocational schools, scientific foundations, industry leaders and other companies; availability of managerial staff and innovations, as well as airports, rail transport, prices of municipal services, flexible policy of banks and the safety level in the region.

\section{Summary}

Choosing the optimal location for a small business providing services on the local market is a strategic decision, the consequences of which will be felt in the future. The determination and commitment of small business owners is understandable because the financial results obtained are the basis for their family's livelihood, and therefore wrong decisions are reflected both in the economic efficiency of the business and are perceived as a personal failure. The very determination of the optimal location is a difficult issue, because, in the variable environment, the service activity is subject to changes and it is adapted to the needs and expectations of the purchaser. In consequence, the hierarchy of location factors also changes. The increase in popularity and availability of ICT (Information and Communication Technologies) among consumers stimulates innovative solutions in some areas, even in those services that have been provided and sold exclusively in the traditional way. To keep up with the competition and the requirements of the buyers, service providers use the Internet (to present their company or offer, to communicate - social media communicators, or platforms for making appointments). A particular intensification of activities has been observed during the pandemic period and in remote working conditions, where the Internet has become an increasingly popular sphere for economic activity. Virtual business then becomes an alternative solution that is impervious to possible restrictions.

In light of the study findings, it can be concluded that the ranking of location factors has changed due to their importance for the development of business activity. In the opinion of the study participants, the optimal location of small service companies offering services in a traditional and/or mixed manner was determined by the following factors: Internet access, potential for the company's spatial expansion, the costs of maintaining the premises, the number of future customers and customer demographic characteristics, closeness of competitors, the cost of building purchase/rental, local taxes and fees and the availability of parking space. Due to their importance for the development of service activities in the community under study, the ranking of location factors presented in this paper shows that the choice of the optimal place of activity is still dependent on many economic aspects; however, the factors associated with technological progress, increasingly present in everyday life, are gaining in importance. The growing popularity of ICT among consumers, as well as their high availability, means that traditional location factors are losing their importance in some types of services, e.g. in the trade in selectable products. The virtualisation of consumer behaviour in the population covered by the survey was relatively low, mainly related to satisfying information needs, and was determined by the types of services represented in the research.

\section{Bibliography}

Borowicz, A., Kostyra, M., Szlutka, S., Wandałowski, M. (2016). Atrakcyjność inwestycyjna województw i podregionów Polski 2016 [Investment Attractiveness of Voivodships and Subregions of Poland 2016]. Warszawa: Instytut Badań nad Gospodarką Rynkową w Gdańsku, Fundacja Konrada Adenaura w Polsce.

Brdulak, J., Pawlak, P., Krysiuk, C., Zakrzewski, B. (2014). Podstawowe teorie lokalizacji działalności gospodarczej oraz znaczenie czynnika transportu [Basic Theories of Business Location and the Importance of the Transport Factor]. Logistyka, (6), 2254-2260.

Budner, W. (2007). Czynniki lokalizacyjne inwestycji a możliwości rozwoju ekonomicznego gmin w Polsce [Localization Investment Factors and the Economic Potential of Polish Municipalities]. Acta Scientarium Polonorum. Administratio Locorum, 6(3): 43-58. 
Celińska-Janowicz, D. (2009). Rozmieszczenie placówek bankowych w Warszawie [Bank Branch Location in Warsaw]. Kwartalnik Naukowy Studia Regionalne i Lokalne, 2(36):105- 117.

CSO, BDL 2017 (www.stat.gov.pl).

Chądzyński, J., Nowakowska, A., Przygodzki, Z., (2007). Region i jego rozwój w warunkach globalizacji [The Region and its Development in the Conditions of Globalisation]. Warszawa: Wydawnictwo CeDeWu.

Czubała, A., Jonas, A., Smoleń, T., Wiktor, J.W. (2012). Marketing usług [Marketing Services]. Warszawa: Wolters Kluwer.

Doligaliski, T. (2013). Internet w zarządzaniu wartościa klienta [The Internet and Customer Value Management]. Warszawa: Oficyna Wydawnicza Szkoła Główna Handlowa w Warszawie.

Gawlikowska-Hueckel, K. (2003). Procesy rozwoju regionalnego w Unii Europejskiej. Konwergencja czy polaryzacja? [The Processes of Regional Development in the European Union. Convergence or Polarisation?]. Gdańsk: Wydawnictwo Uniwersytetu Gdańskiego.

Gilmore, A. (2006). Usługi, marketing, i zarządzanie [Services, Marketing, and Management]. Warszawa: PWE.

Godlewska, H. (2005). Uwarunkowania decyzji lokalizacyjnych [The Determinants of Location]. Warszawa: Wyższa Szkoła Menedżerska w Warszawie.

Kalinowski, T. (2008). Atrakcyjność inwestycyjna regionów i podregionów Polski 2008. [Investment Attractiveness for Poland's Regions and Subregions 2008]. Gdańsk: Instytut Badań nad Gospodarką Rynkową.

Kalinowski, T., Klein, K., Nowicki, M, Sobczak, D., Wojnicka E. (1997). Czynniki lokalizacyjne przedsiębiorstw w województwie słupskim i gdańskim. Wyniki badań ankietowych [Location Factors of Enterprises in the Słupsk and Gdańsk Voivodeships. Survey results]. Gdańsk: Instytut Badań Nad Gospodarką.

Kucharska, B. (ed.). (2010). Obsługa klienta w przedsiębiorstwie handlu detalicznego [Customer Service in a Retail Business]. Katowice: Wydawnictwo Akademii Ekonomicznej w Katowicach.

Matejun, M., Szymańska, K. (2013). Perspektywy rozwoju przedsiębiorczości w warunkach niepewności i ryzyka [Prospects for Business Development in Conditions of Uncertainty and Risk]. Łódź: Monografie Politechniki Łódzkiej.

Mielnicki, A. (2020). The region lures investors. Gazeta Olsztyńska, 01.07.2020 (http://gazetaolsztynska.pl/653665,REGION-KUSI-INWESTOROW.html?fbclid=IwAR2IZZy|Kp0LpffpyOd4 5KLm7omtFuaFVolto8JBt04t2AjP2glgayYUfXI, Retrieved 06.07.2020).
Mikołajczyk, B. (2016). Lokalizacja jako czynnik wyboru usług [Localization as a Factor in the Choice of Services]. Studia Ekonomiczne. Zeszyty Naukowe Uniwersytetu Ekonomicznego w Katowicach, Katowice (30): 138-149.

Moszczyński, M. (2007). Procesy delokalizacji we współczesnej gospodarce światowej - szansa czy zagrożenie dla polskiego rynku pracy [Processes of Relocation in Today's World Economy - an opportunity or a threat to the Polish labour market]. In: Wykorzystanie zasobów pracy we współczesnej gospodarce [The Use of Labour Resources in the Modern Economy]. Szczecin: Katedra Mikroekonomii Uniwersytetu Szczecińskiego (http://mikroekonomia.net/system/publication_files/351/original/ 3.pdf?1314956713 Retrieved 10.07.2020).

Nazarczuk, J. (2013). Potencjał rozwojowy a aktywność inwestycyjna województw i podregionów Polski [Development Potential and Investment Activity of Voivodships and Subregions of Poland]. Olsztyn: Wydawnictwo Uniwersytetu Warmińsko-Mazurskiego w Olsztynie, Olsztyn.

Pine, J. (1993). Mass Customization: The New Frontier in Business Competition. Boston, Massachusetts: Harvard Business School Press.

Plawgo, B., Chilicka, E. (2008). Lokalizacyjne uwarunkowania konkurencyjności przedsiębiorstw sektora rolno-spożywczego w województwie podlaskim [Location Determinants of the Competitiveness of Enterprises in the Agrifood Sector in Podlaskie Voivodeship]. In: Bocian, A.F. (ed.). Rozwój regionalny a rozwój zrównoważony [Regional Development and Sustainable Development]. Białystok: Wydawnictwo Uniwersytetu w Białymstoku.

Pluta-Olearnik, M. (1993). Marketing usług [Marketing Services]. Warszawa: PWE.

Porter M.E. (2001). Porter o konkurencji [Porter on Competition]. Warszawa: PWE.

Szymańska, A.l., Płaziak, M. (2014). Rola nowoczesnych czynników lokalizacji w procesie decyzyjnym przedsiębiorstw na przykładzie firm sektora budowlanego. [The Role of Modern Location Factors in the Decision-making Process of Enterprises on the Example of Companies from the Construction Sector. Przedsiębiorczość. Edukacja (Uniwersytet Pedagogiczny w Krakowie), (10): 71-83.

Waldziński, D. (2005). Polityka regionalna w Polsce $w$ procesie przemian kulturowo-cywilizacyjnych [Regional Policy in Poland in the Context of Cultural and Civilizational Transformations]. Olsztyn: Wydawnictwo Uniwersytetu Warmińsko-Mazurskiego w Olsztynie. 
Wiechoczek, J. (2018). Koncepcja masowej kastomizacji w kreowaniu wartości dla nabywców produktów wybieralnych [The Concept of Mass Customization in Creating Value for the Buyers of Selectable Products]. Handel Wewnętrzny, 4(375), 116-126.

Wieloński, A. (2004). Lokalizacja działalności gospodarczej. Teoretyczne podstawy [The Localisation of a Business Activity. Theoretical Aspects]. Warszawa: Wydawnictwo Uniwersytetu Warszawskiego.

Wierzbicka, W. (2015). Czynniki lokalizacji przedsiębiorstw w warunkach zmienności otoczenia [Factors Governing the Location of Enterprises during Change and Variance]. Zeszyty Naukowe Uniwersytetu Przyrodniczo-Humanistycznego w Siedlcach, Seria Administracja i Zarządzanie, (106): 239-250.

Wolny, R. (2013). Rynek e-usług w Polsce. Funkcjonowanie i kierunki rozwoju [The e-services Market in Poland. Functioning and Directions of Development]. Katowice: Wydawnictwo Uniwersytetu Ekonomicznego w Katowicach. 